\title{
Is Not It Time to Stop Using Chlorine for Treating Water?
}

\author{
Djamel Ghernaout ${ }^{1,2 *}$, Noureddine Elboughdiri ${ }^{1,3}$ \\ ${ }^{1}$ Chemical Engineering Department, College of Engineering, University of Ha'il, Ha'il, KSA \\ ${ }^{2}$ Chemical Engineering Department, Faculty of Engineering, University of Blida, Blida, Algeria \\ ${ }^{3}$ Département de Génie Chimique de Procédés, Laboratoire Modélisation, Analyse, et Commande des systèmes, Ecole Nationale \\ d'Ingénieurs de Gabès (ENIG), Rue Omar Ibn-Elkhattab, Gabès, Tunisia \\ Email: ^djamel_andalus@hotmail.com
}

How to cite this paper: Ghernaout, D. and Elboughdiri, N. (2020) Is Not It Time to Stop Using Chlorine for Treating Water? Open Access Library Journal, 7: e6007. https://doi.org/10.4236/oalib.1106007

Received: December 17, 2019

Accepted: January 7, 2020

Published: January 10, 2020

Copyright (c) 2020 by author(s) and Open Access Library Inc.

This work is licensed under the Creative Commons Attribution International License (CC BY 4.0).

http://creativecommons.org/licenses/by/4.0/ (c) (i) Open Access

\begin{abstract}
Chlorine is largely used as a disinfectant in the water and wastewater treatment industries through the world despite the fact that is greatly poisonous for human beings. Its toxicity is more extended to generating disinfection by-products during its microorganisms' killing and action on organic matter present in water. More importantly, recent studies proved the potential impacts of disinfection on transmission of antibiotic resistance genes (ARGs), particularly for free-living ARGs in final disinfected effluent of urban wastewater treatment plants. Indeed, Escherichia coli concentration prior to chlorination depicted a powerful positive correlation with the extracellular ARGs plenty in the final effluents; however, lower temperature and higher ammonium concentration were suggested to relate with intracellular ARGs. Chlorination could elevate the plenty of ARGs, therefore, inducing danger of the diffusion of antibiotic resistance in nature. Consequently, chlorine toxicity is more and more proved, which appeals its urgent stopping from using it in the treatment of both water and wastewater. The same conclusion was also obtained at least for $\mathrm{UV}$ and $\mathrm{UV} / \mathrm{H}_{2} \mathrm{O}_{2}$ disinfection. Chemical disinfection should be urgently avoided or at least deeply revised. For removing pathogens and treating water, safe multi-barrier methods, such as distillation and membrane processes, have to be adopted.
\end{abstract}

\section{Subject Areas}

Environmental Sciences, Hydrology

\section{Keywords}

Antibiotic-Resistant Bacteria (ARB), Antibiotic Resistance Genes (ARGs), Wastewater Treatment, Disinfection, Oxidation, Escherichia coli 


\section{Introduction}

Antibiotic resistance has caused massive dangers to public health globally [1]. Every year, more than 700,000 persons die from antimicrobial-resistant infections worldwide; nevertheless, the envisaged disaster number risks to attain 10 million by 2050 if no measures are made immediately [2]. Even if the diffusion of antibiotic resistance in clinic environments has appealed considerable worries, the appearance and propagation of antibiotic resistance bacteria (ARB) or antibiotic resistance genes (ARGs) in natural environments have been disregarded yet [3].

Urban wastewater treatment plants (UWWTPs) remain at the interface joining the human population and the aquatic/soil mediums [4]-[10]. They can supply an exemplary environment for the procuration and dispersal of antibiotic resistance [11] [12] [13]. Due to an assorted blend of antibiotics and different contaminants, their metabolites and resistant bacteria attain UWWTPs via wastewater discharges from hospitals, households, industries, and animal farms [14]. The spread of ARB and ARGs in UWWTPs has caught more and more awareness lately [15] [16] [17] [18]. Especially, biological reactors [19] [20] [21] in activated sludge setups are considered as one of the serious boxes in nursing both ARB and ARGs [22] [23], via picking below subjection of antibiotic or resistance transfer between bacteria through horizontal gene transfer (HGT) [24] [25]. In particular, it has been mentioned that UWWTPs display restricted potential to eliminate or restrain ARGs and ARB [17] [26] [27]. More importantly, not only does the effluent constitute a huge tank comprising diverse ARGs, but also the plenties of several exemplary ARGs are surprisingly higher in effluent than that in influent through the treatment techniques, such as blaCTX-M, blaTEM and qnrS [28] [29]. As a result, UWWTPs have been established to function a key part in the transmission of ARB and ARGs in nature, therefore causing hazards to public health [1].

To dominate the prevalence of microorganisms, different disinfection techniques have been largely employed in UWWTPs. Several investigations have studied the demobilization of ARGs via disinfection technologies like chlorination and ultraviolet (UV) irradiation [30] [31] [32] [33]. Nevertheless, not many new investigations mentioned that chlorination, as a largely utilized disinfection method, might co-select antibiotic resistance. As an illustration, Shi et al. [29] affirmed that the chlorination method augmented the plenties of ampC and tet $A$ following metagenomic sequencing. Further, Xu et al. [34] published that chlorination elevated the comparative plenty of ARGs from 6.4- to 109.2-fold in tap water contrasted to the final water. On the other hand, Lin et al. [35] proposed that ARGs were more possibly eliminated rather than co-selected via chlorine, where they monitored 225 ARGs; however, only six were elevated following chlorination. Even if paradoxical deductions were gained concerning the effect of chlorination on ARGs, a small number of researches have been devoted to discerning among intracellular ARGs (iARGs) and extracellular ARG (eARGs). 
Indeed, disinfection techniques (like chlorination) may destroy ARB; however, at the same time, DNA will be liberated into the water, where eARGs may remain existing in the free-living DNA. The presence of iARGs can assist ARB dispersal through conjugation and transduction; however, the competent non-resistant bacteria in the biofilm and sedimentation can take up eARGs stability in the aquatic medium for quite a time, that way conducting to the diffusion of antibiotic resistance through transformation [36] [37] [38]. Consequently, eARGs in the effluent from UWWPTs are also possible to raise ARGs and ARB transmission in environmental mediums. Nevertheless, the influence of chlorination on eARGs stays ambiguous because of the shortage of an efficacious procedure to extract extracellular DNA (eDNA), which is too small to collect in treated water. Lately, Wang et al. [38] presented a procedure to collect eDNA via employing a novel kind of nucleic acid adsorption particle (NAAP) with an elevated potential, which may attain an eARG recuperation average of more than 95\% from $10 \mathrm{~L}$ of water samples. This advanced procedure may let us examine the effect of disinfection on eARGs [1].

\section{Chlorination Augments Both iARGs and eARGs}

Liu et al. [1] examined the impacts of chlorination on the presence and concentration of both eARGs and iARGs in a full-scale UWWTP during twelve months. They indicated that the concentrations of both eARGs and iARGs could be elevated via disinfecting with chlorine dioxide $\left(\mathrm{ClO}_{2}\right)$. More importantly, chlorination preferentially augmented the plenties of eARGs versus macrolide (erm $B)$, tetracycline (tet $A, \operatorname{tet} B$ and tetC), sulfonamide (sul, suh and suß), $\beta$-lactam $(\operatorname{ampC})$, aminoglycosides (aph(2')-Id), rifampicin (katG) and vancomycin ( $\operatorname{van} A)$ up to 3.8 folds. In the same way, the plenties of iARGs were also elevated up to 7.8 folds following chlorination. In terms of correlation analyses, the plenty of Escherichia coli prior chlorination depicted a powerful positive correlation with the total eARG concentration; however, lower temperature and higher ammonium concentration were supposed to be linked with the concentration of iARGs. Liu et al. [1] concluded the chlorination could elevate the plenties of both iARGs and eARGs, just like that causing danger of the diffusion of antibiotic resistance in nature.

\section{Microbial Selectivity of UV Treatment on Antibiotic-Resistant Bacteria}

To comprehend the influence of UV disinfection on antibiotic-resistant bacteria, Guo et al. [39] investigated both total heterotrophic bacteria, and antibiotic-resistant bacteria (comprising cephalexin-, ciprofloxacin-, erythromycin-, gentamicin-, vancomycin-, sulfadiazine-, rifampicin-, tetracycline- and chloramphenicol-resistant bacteria) in secondary effluent samples from a domestic wastewater treatment plant (Figure 1). Bacteria resistant to both erythromycin and tetracycline were selected as the specimen of multiple-antibiotic-resistant 


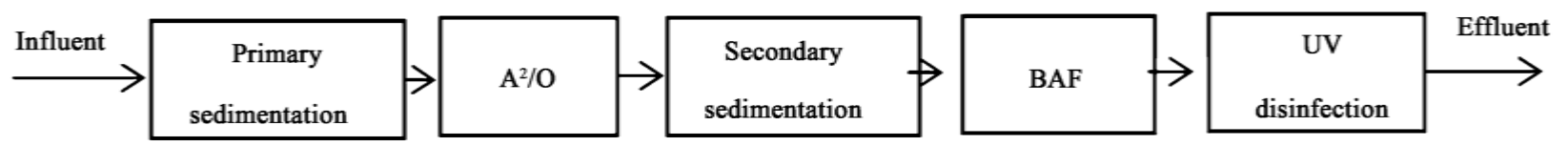

Figure 1. Treatment process of the municipal wastewater treatment plant (A²/O: Anaerobic-Anoxic-Oxicprocess; BAF: Biological Aerated Filter) [39].

bacteria and their properties following UV application were also examined. They found that UV disinfection conducts to performant demobilization of total heterotrophic bacteria, as well as all antibiotic-resistant bacteria. Following UV application at a fluence of $5 \mathrm{~mJ} / \mathrm{cm}^{2}$, the log decreases of nine types of antibiotic-resistant bacteria changed from $1.0 \pm 0.1$ to $2.4 \pm 0.1$. Bacteria resistant to both erythromycin and tetracycline had an identical fluence reaction as did total heterotrophic bacteria. Their results propose that UV disinfection could remove antibiotic resistance in wastewater treatment effluents and therefore guarantee public health security. Guo et al. [39] mentioned that UV disinfection conducted to the enrichment of bacteria with resistance to sulfadiazine, vancomycin, rifampicin, tetracycline and chloramphenicol; however, the fractions of cephalexin-, erythromycin-, gentamicin- and ciprofloxacin-resistant bacteria in the wastewater diminished. This illustrates the microbial selectivity of UV disinfection for antibiotic-resistant bacteria.

\section{Antibiotic Resistance Diffusion Capacity by $\mathrm{UV} / \mathrm{H}_{2} \mathrm{O}_{2}$ Technique}

Ferro et al. [40] assessed the influence of an advanced oxidation process (particularly $\mathrm{UV} / \mathrm{H}_{2} \mathrm{O}_{2}$ ) [41]-[46] on antibiotic resistance diffusion capacity. They performed $\mathrm{UV} / \mathrm{H}_{2} \mathrm{O}_{2}$ disinfection trials on real wastewater samples to estimate the: 1) demobilization of Total Coliforms, E. coli, and antibiotic-resistant E. coli as well as 2) probable elimination of objective ARGs (that is, bla $a_{\text {тем }}$, $q$ nr $S$ and tet $\mathrm{W}$ ) (Figure 2). Especially, DNA was extracted from both antibiotic-resistant E. coli bacterial cells (intracellular DNA), grown on selective culture media, and the whole water suspension (total DNA) collected at various treatment periods. Polymerase chain reaction (PCR) check was realized to discover the absence/presence of the selected ARGs. Real Time quantitative Polymerase Chain Reaction (qPCR) was employed to measure the studied ARGs in terms of copies/mL. Regardless of the bacterial demobilization and a diminution of ARGs in intracellular DNA following 60 min treatment, $\mathrm{UV} / \mathrm{H}_{2} \mathrm{O}_{2}$ method was not performant in eliminating ARGs from water suspension (total DNA). More importantly, an augmentation up to $3.7 \times 10^{3}$ copies $/ \mathrm{mL}$ ( $\mathrm{p} \mathrm{N} 0.05$ ) of bla $a_{\mathrm{TEM}}$ gene was noted in total DNA following 240 min treatment; however, no variation ( $\mathrm{p}>$ $0.05)$ was observed for $q n r S$ gene among the initial $\left(5.1 \times 10^{4}\right.$ copies $\left./ \mathrm{mL}\right)$ and the final sample $\left(4.3 \times 10^{4}\right.$ copies $/ \mathrm{mL}$ ) (Figure 3$)$. Following their findings, Ferro et al. [40] concluded that the examined disinfection technique might not be able to diminish antibiotic resistance diffusion capacity. 


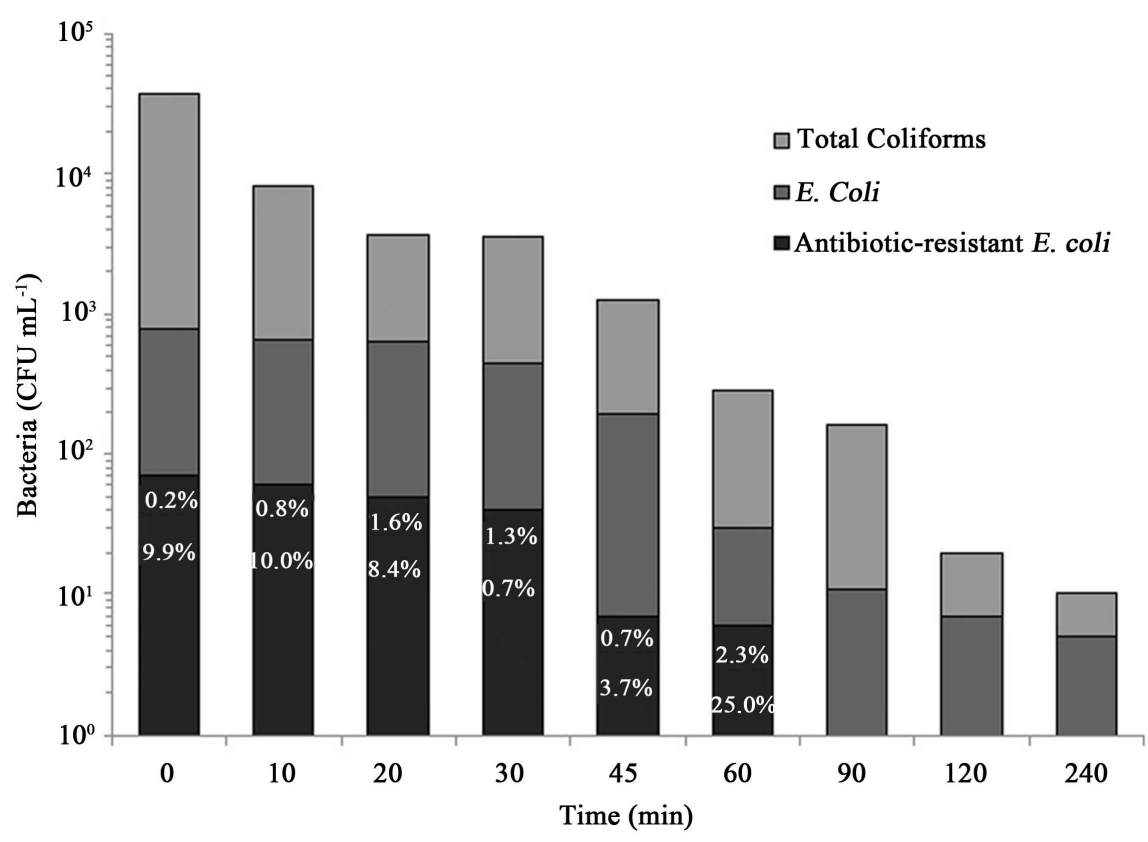

Figure 2. Relative abundance of bacterial population during $\mathrm{UV} / \mathrm{H}_{2} \mathrm{O}_{2}$ treatment and AntibioticResistant $E$. coli percentages calculatedwith respect to total coliforms (upper placed values) and E. coli [40].

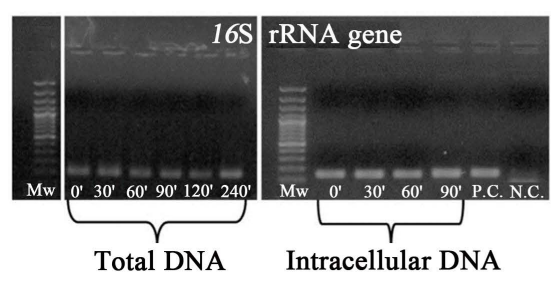

(a)

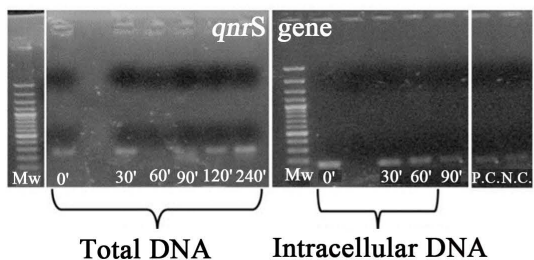

(c)

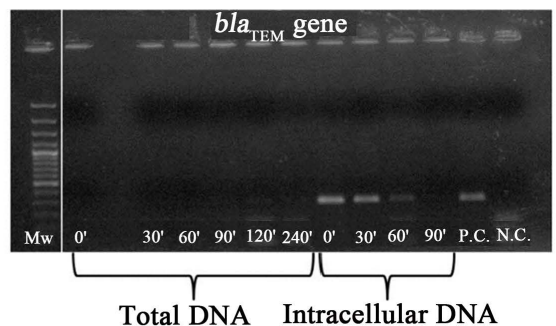

(b)

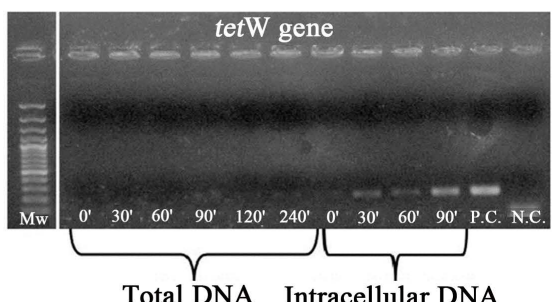

(d)

Figure 3. Results of electrophoretic run of PCR product on gel agarose: 16S rRNA gene (a); blaтем gene (b); qnrS gene (c); tet Wgene (d). P.C. = positive control; N.C. = negative control [40].

\section{Electrodis Infection of Bacteria}

Electrodisinfection has been illustrated to be an efficacious technique with low needed residence period for treating potable water supplies, industrial raw water supplies, liquid foodstuffs, and wastewater effluents [47]-[52]. Ghasemian et al. [53] explored the electrodis infection of saline water polluted with bacteria in chloride-containing solutions employing Sb-doped $\mathrm{Sn}_{80 \%}-\mathrm{W}_{20 \%}$-oxide anodes. 
They focused on the impact of current density, bacterial load, initial chloride concentration, solution $\mathrm{pH}$, and the kind of bacteria (E. coli D21, E. coli O157: $\mathrm{H} 7$, and $E$. faecalis) on disinfection performance. They tested the influence of the natural organic matter [54]-[60] and a radical scavenger on the disinfection efficiency. They found that their electrochemical setup was greatly efficient in demobilizing bacteria for a $0.1 \mathrm{M} \mathrm{NaCl}$ solution polluted with $\sim 10^{7} \mathrm{CFU} / \mathrm{mL}$ bacteria via implementing a current density $\geq 1 \mathrm{~mA} / \mathrm{cm}^{2}$ over the cell. They attained $100 \%$ demobilization of $E$. coli D21 during less than $60 \mathrm{~s}$ and power consumption of $48 \mathrm{Wh} / \mathrm{m}^{3}$, via implementing a current density of $6 \mathrm{~mA} / \mathrm{cm}^{2}$ in a $0.1 \mathrm{M}$ $\mathrm{NaCl}$ solution polluted with $\sim 10^{7} \mathrm{CFU} / \mathrm{mL}$. Reactive chlorine species as well as reactive oxygen species (such as hydroxyl radicals) [61], formed in situ throughout the electrochemical technology, were discovered to be in charge of demobilizing bacteria.

\section{Conclusions}

The main points drawn from this work may be given as:

1) Chlorination augmented both eARGs and iARGs contamination in a full-scale UWWTP. E. coli concentration prior to chlorination depicted a powerful positive correlation with the eARGs plenty in the final effluents; however, lower temperature and higher ammonium concentration were suggested to relate with iARGs. Chlorination could elevate the plenty of ARGs, therefore inducing danger of the diffusion of antibiotic resistance in nature [1].

2) As the UV fluence used in actual WWTPs for disinfecting wastewater is usually less than the design parameters, regarding the life span and running circumstances of UV lamps, the potential hazard augmented by ARB following implementations of low fluences still needs awareness. For this reason, ARB removal researches of UV disinfection or different disinfection techniques in WWTPs are necessitated [39].

3) Consequently, chlorine toxicity is more and more established. This implicates its urgent stopping from using it in the treatment of both water and wastewater [62]. Chemical disinfection should be deeply avoided or at least revised [63]-[68]. For removing pathogens and treating water, safe multi-barrier processes, such as distillation and membrane processes [69]-[78], have to be adopted for the best future of humankind [79] [80] [81].

\section{Conflicts of Interest}

The authors declare no conflicts of interest regarding the publication of this paper.

\section{References}

[1] Liu, S.-S., Qu, H.-M., Yang, D., Hu, H., Liu, W.-L., Qiu, Z.-G., Hou, A.-M., Guo, J., Li, J.-W., Shen, Z.-Q. and Jin, M. (2018) Chlorine Disinfection Increases Both Intracellular and Extracellular Antibiotic Resistance Genes in a Full-Scale Wastewater Treatment Plant. Water Research, 136, 131-136. 
https://doi.org/10.1016/j.watres.2018.02.036

[2] O’Neill, J. (2015) Review on Antimicrobial Resistance. Tackling a Crisis for the Health and Wealth of Nations.

[3] Huang, J.-J., Hu, H.-Y., Lu, S.-Q., Li, Y., Tang, F., Lu, Y. and Wei, B. (2012) Monitoring and Evaluation of Antibiotic-Resistant Bacteria at a Municipal Wastewater Treatment Plant in China. Environment International, 42, 31-36. https://doi.org/10.1016/j.envint.2011.03.001

[4] Koivunen, J. and Heinonen-Tanski, H. (2005) Inactivation of Enteric Microorganisms with Chemical Disinfectants, UV Irradiation and Combined Chemical/UV Treatments. Water Research, 39, 1519-1526. https://doi.org/10.1016/j.watres.2005.01.021

[5] Kitis, M. (2004) Disinfection of Wastewater with Peracetic Acid: A Review. Environment International, 30, 47-55. https://doi.org/10.1016/S0160-4120(03)00147-8

[6] Al-Jassim, N., Ansari, M.I., Harb, M. and Hong, P.-Y. (2015) Removal of Bacterial Contaminants and Antibiotic Resistance Genes by Conventional Wastewater Treatment Processes in Saudi Arabia: Is the Treated Wastewater Safe to Reuse for Agricultural Irrigation? Water Research, 73, 277-290. https://doi.org/10.1016/j.watres.2015.01.036

[7] Ghernaout, D. (2013) The Best Available Technology of Water/Wastewater Treatment and Seawater Desalination: Simulation of the Open Sky Seawater Distillation. Green and Sustainable Chemistry, 3, 68-88. https://doi.org/10.4236/gsc.2013.32012

[8] Ghernaout, D. (2018) Increasing Trends towards Drinking Water Reclamation from Treated Wastewater. World Journal of Applied Chemistry, 3, 1-9. https://doi.org/10.11648/j.wjac.20180301.11

[9] Ghernaout, D., Alshammari, Y. and Alghamdi, A. (2018) Improving Energetically Operational Procedures in Wastewater Treatment Plants. International Journal of Advanced and Applied Sciences, 5, 64-72. https://doi.org/10.21833/ijaas.2018.09.010

[10] Al Arni, S., Amous, J. and Ghernaout, D. (2019) On the Perspective of Applying of a New Method for Wastewater Treatment Technology: Modification of the Third Traditional Stage with Two Units, One by Cultivating Microalgae and Another by Solar Vaporization. International Journal of Environmental Sciences \& Natural Resources, 16, Article ID: 555934. https://doi.org/10.19080/IJESNR.2019.16.555934

[11] Ghernaout, D., Elboughdiri, N. and Al Arni, S. (2019) Water Reuse (WR): Dares, Restrictions, and Trends. Applied Engineering, 3, 159-170.

[12] Ghernaout, D., Elboughdiri, N. and Ghareba, S. (2019) Drinking Water Reuse: One-Step Closer to Overpassing the "Yuck Factor". Open Access Library Journal, 6, e5895. https://doi.org/10.4236/oalib.1105895

[13] Ghernaout, D. (2017) Water Reuse (WR): The Ultimate and Vital Solution for Water Supply Issues. International Journal of Sustainable Development Research, 3, 36-46. https://doi.org/10.11648/j.ijsdr.20170304.12

[14] Guo, J., Li, J., Chen, H., Bond, P.L. and Yuan, Z. (2017) Metagenomic Analysis Reveals Wastewater Treatment Plants as Hotspots of Antibiotic Resistance Genes and Mobile Genetic Elements. Water Research, 123, 468-478.

https://doi.org/10.1016/j.watres.2017.07.002

[15] Chen, H. and Zhang, M. (2013) Occurrence and Removal of Antibiotic Resistance Genes in Municipal Wastewater and Rural Domestic Sewage Treatment Systems in Eastern China. Environment International, 55, 9-14. https://doi.org/10.1016/j.envint.2013.01.019

[16] Naquin, A., Shrestha, A., Sherpa, M., Nathaniel, R. and Boopathy, R. (2015) Pres- 
ence of Antibiotic Resistance Genes in a Sewage Treatment Plant in Thibodaux, Louisiana, USA. Bioresource Technology, 188, 79-83. https://doi.org/10.1016/j.biortech.2015.01.052

[17] Wang, Q., Mao, D. and Luo, Y. (2015) Ionic Liquid Facilitates the Conjugative Transfer of Antibiotic Resistance Genes Mediated by Plasmid RP4. Environmental Science \& Technology, 49, 8731-8740. https://doi.org/10.1021/acs.est.5b01129

[18] Wen, Q., Yang, L., Duan, R. and Chen, Z. (2016) Monitoring and Evaluation of Antibiotic Resistance Genes in Four Municipal Wastewater Treatment Plants in Harbin, Northeast China. Environmental Pollution, 212, 34-40. https://doi.org/10.1016/j.envpol.2016.01.043

[19] Ghernaout, D. and Ghernaout, B. (2012) On the Concept of the Future Drinking Water Treatment Plant: Algae Harvesting from the Algal Biomass for Biodiesel Production-A Review. Desalination and Water Treatment, 49, 1-18. https://doi.org/10.1080/19443994.2012.708191

[20] Ghernaout, D. (2019) Reviviscence of Biological Wastewater Treatment-A Review. Applied Engineering, 3, 46-55.

[21] Ghernaout, D. (2019) Electrocoagulation Process for Microalgal Biotechnology-A Review. Applied Engineering, 3, 85-94.

[22] Rizzo, L., Manaia, C., Merlin, C., Schwartz, T., Dagot, C., Ploy, M.C., Michael, I. and Fatta-Kassinos, D. (2013) Urban Wastewater Treatment Plants as Hotspots for Antibiotic Resistant Bacteria and Genes Spread into the Environment: A Review. Science of the Total Environment, 447, 345-360. https://doi.org/10.1016/j.scitotenv.2013.01.032

[23] Yang, Y., Zhang, T., Zhang, X.X., Liang, D.W., Zhang, M., Gao, D.W., Zhu, H.G., Huang, Q.G. and Fang, H.H. (2012) Quantification and Characterization of Betalactam Resistance Genes in 15 Sewage Treatment Plants from East Asia and North America. Applied Microbiology and Biotechnology, 95, 1351-1358. https://doi.org/10.1007/s00253-011-3810-5

[24] Jutkina, J., Rutgersson, C., Flach, C.F. and Larsson, D.G. (2016) An Assay for Determining Minimal Concentrations of Antibiotics That Drive Horizontal Transfer of Resistance. Science of the Total Environment, 548-549, 131-138. https://doi.org/10.1016/j.scitotenv.2016.01.044

[25] Kim, S., Yun, Z., Ha, U.H., Lee, S., Park, H., Kwon, E.E., Cho, Y., Choung, S., Oh, J., Medriano, C.A. and Chandran, K. (2014) Transfer of Antibiotic Resistance Plasmids in Pure and Activated Sludge Cultures in the Presence of Environmentally Representative Micro-Contaminant Concentrations. Science of the Total Environment, 468-469, 813-820. https://doi.org/10.1016/j.scitotenv.2013.08.100

[26] Munir, M., Wong, K. and Xagoraraki, I. (2011) Release of Antibiotic Resistant Bacteria and Genes in the Effluent and Biosolids of Five Wastewater Utilities in Michigan. Water Research, 45, 681-693. https://doi.org/10.1016/j.watres.2010.08.033

[27] Pruden, A., Pei, R., Storteboom, H. and Carlson, K.H. (2006) Antibiotic Resistance Genes as Emerging Contaminants: Studies in Northern Colorado. Environmental Science \& Technology, 40, 7445-7450. https://doi.org/10.1021/es0604131

[28] Rodriguez-Mozaz, S., Chamorro, S., Marti, E., Huerta, B., Gros, M., Sanchez-Melsio, A., Borrego, C.M., Barcelo, D. and Balcazar, J.L. (2015) Occurrence of Antibiotics and Antibiotic Resistance Genes in Hospital and Urban Wastewaters and Their Impact on the Receiving River. Water Research, 69, 234-242. https://doi.org/10.1016/j.watres.2014.11.021

[29] Shi, P., Jia, S., Zhang, X.X., Zhang, T., Cheng, S. and Li, A. (2013) Metagenomic In- 
sights into Chlorination Effects on Microbial Antibiotic Resistance in Drinking Water. Water Research, 47, 111-120. https://doi.org/10.1016/j.watres.2012.09.046

[30] McKinney, C.W. and Pruden, A. (2012) Ultraviolet Disinfection of Antibiotic Resistant Bacteria and Their Antibiotic Resistance Genes in Water and Wastewater. Environmental Science \& Technology, 46, 13393-13400.

https://doi.org/10.1021/es303652q

[31] Yoon, Y., Chung, H.J., Di, D.Y.W., Dodd, M.C., Hur, H.-G. and Lee, Y. (2017) Inactivation Efficiency of Plasmid-Encoded Antibiotic Resistance Genes during Water Treatment with Chlorine, UV, and $\mathrm{UV} / \mathrm{H}_{2} \mathrm{O}_{2}$. Water Research, 123, 783-793. https://doi.org/10.1016/j.watres.2017.06.056

[32] Zhang, Y., Zhuang, Y., Geng, J., Ren, H., Zhang, Y., Ding, L. and Xu, K. (2015) Inactivation of Antibiotic Resistance Genes in Municipal Wastewater Effluent by Chlorination and Sequential UV/Chlorination Disinfection. Science of the Total Environment, 512-513, 125-132. https://doi.org/10.1016/j.scitotenv.2015.01.028

[33] Lin, W., Li, S., Zhang, S. and Yu, X. (2016) Reduction in Horizontal Transfer of Conjugative Plasmid by UV Irradiation and Low-Level Chlorination. Water Research, 91, 331-338. https://doi.org/10.1016/j.watres.2016.01.020

[34] Xu, L., Ouyang, W., Qian, Y., Su, C., Su, J. and Chen, H. (2016) High-Throughput Profiling of Antibiotic Resistance Genes in Drinking Water Treatment Plants and Distribution Systems. Environmental Pollution, 213, 119-126. https://doi.org/10.1016/j.envpol.2016.02.013

[35] Lin, W., Zhang, M., Zhang, S. and Yu, X. (2016) Can Chlorination Co-Select Antibiotic-Resistance Genes? Chemosphere, 156, 412-419.

https://doi.org/10.1016/j.chemosphere.2016.04.139

[36] Li, Y.H., Lau, P.C., Lee, J.H., Ellen, R.P. and Cvitkovitch, D.G. (2001) Natural Genetic Transformation of Streptococcus mutans Growing in Biofilms. Journal of Bacteriology, 183, 897-908. https://doi.org/10.1128/JB.183.3.897-908.2001

[37] Molin, S. and Tolker-Nielsen, T. (2003) Gene Transfer Occurs with Enhanced Efficiency in Biofilms and Induces Enhanced Stabilisation of the Biofilm Structure. Current Opinion in Biotechnology, 14, 255-261. https://doi.org/10.1016/S0958-1669(03)00036-3

[38] Wang, D.N., Liu, L., Qiu, Z.G., Shen, Z.Q., Guo, X., Yang, D., Li, J., Liu, W.L., Jin, M. and Li, J.W. (2016) A New Adsorption-Elution Technique for the Concentration of Aquatic Extracellular Antibiotic Resistance Genes from Large Volumes of Water. Water Research, 92, 188-198. https://doi.org/10.1016/j.watres.2016.01.035

[39] Guo, M.-T., Yuan, Q.-B. and Yang, J. (2013) Microbial Selectivity of UV Treatment on Antibiotic-Resistant Heterotrophic Bacteria in Secondary Effluents of a Municipal Wastewater Treatment Plant. Water Research, 47, 6388-6394.

https://doi.org/10.1016/j.watres.2013.08.012

[40] Ferro, G., Guarino, F., Castiglione, S. and Rizzo, L. (2016) Antibiotic Resistance Spread Potential in Urban Wastewater Effluents Disinfected by $\mathrm{UV} / \mathrm{H}_{2} \mathrm{O}_{2}$ Process. Science of the Total Environment, 560-561, 29-35.

https://doi.org/10.1016/j.scitotenv.2016.04.047

[41] Ghernaout, D. and Naceur, M.W. (2011) Ferrate (VI): In Situ Generation and Water Treatment-A Review. Desalination and Water Treatment, 30, 319-332. https://doi.org/10.5004/dwt.2011.2217

[42] Ghernaout, D. (2013) Advanced Oxidation Phenomena in Electrocoagulation Process: A Myth or a Reality? Desalination and Water Treatment, 51, 7536-7554. https://doi.org/10.1080/19443994.2013.792520 
[43] Ghernaout, D. (2019) Virus Removal by Electrocoagulation and Electrooxidation: New Findings and Future Trends. Journal of Environmental Science and Allied Research, 85-90.

[44] Ghernaout, D. (2019) Electrocoagulation and Electrooxidation for Disinfecting Water: New Breakthroughs and Implied Mechanisms. Applied Engineering, 3, 125-133.

[45] Ghernaout, D. and Elboughdiri, N. (2019) Mechanistic Insight into Disinfection Using Ferrate (VI). Open Access Library Journal, 6, e5946.

[46] Ghernaout, D. and Elboughdiri, N. (2019) Water Disinfection: Ferrate (VI) as the Greenest Chemical-A Review. Applied Engineering, 3, 171-180.

[47] Ghernaout, D., Badis, A., Ghernaout, B. and Kellil, A. (2008) Application of Electrocoagulation in Escherichia coli Culture and Two Surface Waters. Desalination, 219, 118-125. https://doi.org/10.1016/j.desal.2007.05.010

[48] Ghernaout, D. and Ghernaout, B. (2010) From Chemical Disinfection to Electrodisinfection: The Obligatory Itinerary? Desalination and Water Treatment, 16, 156-175. https://doi.org/10.5004/dwt.2010.1085

[49] Ghernaout, D., Benblidia, C. and Khemici, F. (2015) Microalgae Removal from Ghrib Dam (AinDefla, Algeria) Water by Electroflotation Using Stainless Steel Electrodes. Desalination and Water Treatment, 54, 3328-3337. https://doi.org/10.1080/19443994.2014.907749

[50] Ghernaout, D. (2017) Microorganisms' Electrochemical Disinfection Phenomena. EC Microbiology, 9, 160-169.

[51] Ghernaout, D., Alghamdi, A. and Ghernaout, B. (2019) Microorganisms' Killing: Chemical Disinfection vs. Electrodisinfection. Applied Engineering, 3, 13-19.

[52] Ghernaout, D. (2019) Disinfection via Electrocoagulation Process: Implied Mechanisms and Future Tendencies. EC Microbiology, 15, 79-90.

[53] Ghasemian, S., Asadishad, B., Omanovic, S. and Tufenkji, N. (2017) Electrochemical Disinfection of Bacteria-Laden Water Using Antimony-Doped Tin-Tungsten-Oxide Electrodes. Water Research, 126, 299-307. https://doi.org/10.1016/j.watres.2017.09.029

[54] Ghernaout, D., Ghernaout, B. and Kellil, A. (2009) Natural Organic Matter Removal and Enhanced Coagulation as a Link between Coagulation and Electrocoagulation. Desalination and Water Treatment, 2, 203-222.

https://doi.org/10.5004/dwt.2009.116

[55] Ghernaout, D., Naceur, M.W. and Ghernaout, B. (2011) A Review of Electrocoagulation as a Promising Coagulation Process for Improved Organic and Inorganic Matters Removal by Electrophoresis and Electroflotation. Desalination and Water Treatment, 28, 287-320. https://doi.org/10.5004/dwt.2011.1493

[56] Ghernaout, D. (2014) The Hydrophilic/Hydrophobic Ratio vs. Dissolved Organics Removal by Coagulation-A Review. Journal of King Saud University-Science, 26, 169-180. https://doi.org/10.1016/j.jksus.2013.09.005

[57] Ghernaout, D., Moulay, S., AitMessaoudene, N., Aichouni, M., Naceur, M.W. and Boucherit, A. (2014) Coagulation and Chlorination of NOM and Algae in Water Treatment: A Review. International Journal of Environmental Monitoring and Analysis, 2, 23-34. https://doi.org/10.11648/j.ijema.s.2014020601.14

[58] Ghernaout, D., Al-Ghonamy, A.I., Boucherit, A., Ghernaout, B., Naceur, M.W., AitMessaoudene, N., Aichouni, M., Mahjoubi, A.A. and Elboughdiri, N.A. (2015) Brownian Motion and Coagulation Process. American Journal of Environmental 
Protection, 4, 1-15. https://doi.org/10.11648/j.ajeps.s.2015040501.11

[59] Ghernaout, D., Al-Ghonamy, A.I., Naceur, M.W., Boucherit, A., Messaoudene, N.A., Aichouni, M., Mahjoubi, A.A. and Elboughdiri, N.A. (2015) Controlling Coagulation Process: From Zeta Potential to Streaming Potential. American Journal of Environmental Protection, 4, 16-27. https://doi.org/10.11648/j.ajeps.s.2015040501.12

[60] Ghernaout, D. and Boucherit, A. (2015) Review of Coagulation's Rapid Mixing for NOM Removal. Journal of Research \& Developments in Chemistry, 2015, Article ID: 926518. https://doi.org/10.5171/2015.926518

[61] Ghernaout, D. (2019) Aeration Process for Removing Radon from Drinking Water: A Review. Applied Engineering, 3, 32-45.

[62] Ghernaout, D. (2017) Environmental Principles in the Holy Koran and the Sayings of the Prophet Muhammad. American Journal of Environmental Protection, 6, 75-79. https://doi.org/10.11648/j.ajep.20170603.13

[63] Boucherit, A., Moulay, S., Ghernaout, D., Al-Ghonamy, A.I., Ghernaout, B., Naceur, M.W., AitMessaoudene, N., Aichouni, M., Mahjoubi, A.A. and Elboughdiri, N.A. (2015) New Trends in Disinfection By-Products Formation upon Water Treatment. Journal of Research \& Developments in Chemistry, 2015, Article ID: 628833. https://doi.org/10.5171/2015.628833

[64] Ghernaout, D. (2018) Disinfection and DBPs Removal in Drinking Water Treatment: A Perspective for a Green Technology. International Journal of Advanced and Applied Sciences, 5, 108-117. https://doi.org/10.21833/ijaas.2018.02.018

[65] Ghernaout, D., Touahmia, M. and Aichouni, M. (2019) Disinfecting Water: Electrocoagulation as an Efficient Process. Applied Engineering, 3, 1-12.

[66] Ghernaout, D. (2017) The Holy Koran Revelation: Iron Is a "Sent Down" Metal. American Journal of Environmental Protection, 6, 101-104. https://doi.org/10.11648/j.ajep.20170604.14

[67] Ghernaout, D., Aichouni, M. and Touahmia, M. (2019) Mechanistic Insight into Disinfection by Electrocoagulation: A Review. Desalination and Water Treatment, 141, 68-81. https://doi.org/10.5004/dwt.2019.23457

[68] Ghernaout, D. (2019) Greening Electrocoagulation Process for Disinfecting Water. Applied Engineering, 3, 27-31.

[69] Ghernaout, D. and El-Wakil, A. (2017) Requiring Reverse Osmosis Membranes Modifications-An Overview. American Journal of Chemical Engineering, 5, 81-88. https://doi.org/10.11648/j.ajche.20170504.15

[70] Ghernaout, D. (2017) Reverse Osmosis Process Membranes Modeling-A Historical Overview. Journal of Civil, Construction and Environmental Engineering, 2, 112-122.

[71] Ghernaout, D., El-Wakil, A., Alghamdi, A., Elboughdiri, N. and Mahjoubi, A. (2018) Membrane Post-Synthesis Modifications and How It Came about. International Journal of Advanced and Applied Sciences, 5, 60-64. https://doi.org/10.21833/ijaas.2018.02.010

[72] Ghernaout, D., Alshammari, Y., Alghamdi, A., Aichouni, M., Touahmia, M. and AitMessaoudene, N. (2018) Water Reuse: Extenuating Membrane Fouling in Membrane Processes. International Journal of Environmental Chemistry, 2, 1-12. https://doi.org/10.11648/j.ajche.20180602.12

[73] Ghernaout, D. (2019) Brine Recycling: Towards Membrane Processes as the Best Available Technology. Applied Engineering, 3, 71-84. 
[74] Ghernaout, D. and Elboughdiri, N. (2019) Electrocoagulation Process Intensification for Disinfecting Water: A Review. Applied Engineering, 3, 140-147.

[75] Ghernaout, D. and Elboughdiri, N. (2019) Iron Electrocoagulation Process for Disinfecting Water: A Review. Applied Engineering, 3, 154-158.

[76] Ghernaout, D., Naceur, M.W. and Aouabed, A. (2011) On the Dependence of Chlorine By-Products Generated Species Formation of the Electrode Material and Applied Charge during Electrochemical Water Treatment. Desalination, 270, 9-22. https://doi.org/10.1016/j.desal.2011.01.010

[77] Ghernaout, D. (2011) Water Treatment Chlorination: An Updated Mechanistic Insight Review. Chemistry Research Journal, 2, 125-138.

[78] AitMessaoudene, N., Naceur, M.W., Ghernaout, D., Alghamdi, A. and Aichouni, M. (2018) On the Validation Perspectives of the Proposed Novel Dimensionless Fouling Index. International Journal of Advanced and Applied Sciences, 5, 116-122. https://doi.org/10.21833/ijaas.2018.07.014

[79] Ghernaout, D., Alghamdi, A., Aichouni, M. and Touahmia, M. (2018) The Lethal Water Tri-Therapy: Chlorine, Alum, and Polyelectrolyte. World Journal of Applied Chemistry, 3, 65-71. https://doi.org/10.11648/j.wjac.20180302.14

[80] Ghernaout, D., Ghernaout, B. and Naceur, M.W. (2011) Embodying the Chemical Water Treatment in the Green Chemistry: A Review. Desalination, 271, 1-10. https://doi.org/10.1016/j.desal.2011.01.032

[81] Ghernaout, B., Ghernaout, D. and Saiba, A. (2010) Algae and Cyanotoxins Removal by Coagulation/Flocculation: A Review. Desalination and Water Treatment, 20, 133-143. https://doi.org/10.5004/dwt.2010.1202 